\title{
Od społecznika do profesjonalisty - ewolucja zawodu pracownika socjalnego w Polsce
}

\author{
KEY WORDS \\ social worker, social \\ work, social care
}

\begin{abstract}
Brenk Mikołaj, Od społecznika do profesjonalisty - ewolucja zawodu pracownika socjalnego w Polsce [From a Social Activist to a Professional - the Evolution of the Occupation of a Social Worker in Poland]. Kultura - Społeczeństwo - Edukacja nr 2, 2012, Poznań 2012, pp. 135-149, Adam Mickiewicz University Press. ISBN 978-83-232-2528-7

There are two main subjects raised in the article, meaning the development of the occupation of a social worker and the pursuit to make the work for the ones in need professional. The latter has its genesis in the actions taken in the period of annexation. Trials to find an efficient method to help people in dealing with life crisis have not been fully achieved yet although lasting over a century. Therefore, there is a question whether and in what extend may the practice of the following decades be used to build the occupation of a social worker, which will gain a status of a profession.
\end{abstract}

Od kilku lat zawód pracownika socjalnego ulega dynamicznym przemianom, których elementem wspólnym jest wzrost wskaźnika profesjonalizacji służb wykonujących zadania z zakresu pomocy społecznej (zob. Leśniak-Berek, Wódz, 2009: 72n). Dążenie do profesjonalizacji pracy na rzecz potrzebujących ma genezę $\mathrm{w}$ działaniach podejmowanych w Polsce w okresie zaborów. Trwające ponad wiek dążenia do wypracowania skutecznej metody pomocy ludziom w wychodzeniu z kryzysów życiowych wciąż nie osiągnęły w pełni swojego rezultatu. Stąd pojawiania się pytanie: czy i na ile można wykorzystać praktykę kolejnych dziesięcioleci do budowania zawodu pracownika socjalnego, który będzie posiadał status profesji?

Podstawę profesjonalnej pracy socjalnej stanowi kanon wiedzy, wartości i umiejętności praktycznych, określony po raz pierwszy w latach siedemdziesiątych przez amerykańskie stowarzyszenie pracowników socjalnych (NASW). Wiedza posiadana przez pracownika socjalnego powinna umożliwić mu właści- 
we zdiagnozowanie potrzeb klientów i udzielenie skutecznej pomocy. Kazimiera Wódz wskazuje, że

podstawą przygotowania zawodowego pracownika socjalnego powinno być ogólne wykształcenie humanistyczne na poziomie uniwersyteckim, uwzględniające wiedzę z zakresu nauk społecznych, politycznych, ekonomii, polityki społecznej, historii pracy socjalnej, metodologii badań społecznych, elementów zarządzania itp. To ogólne wykształcenie powinno być punktem wyjścia do dalszego specjalistycznego kształcenia, w którym najważniejszą rolę odgrywa wiedza z zakresu teorii i metod pracy socjalnej, znajomość różnych obszarów praktyki pracy socjalnej, wiedza z zakresu ustawodawstwa socjalnego, wreszcie znajomość samego siebie i doświadczenie obcowania z przedstawicielami grup mniejszościowych, kulturowych, etnicznych, czy społecznych. (Wódz, 1999: 139)

Drugim elementem kanonu jest posiadanie przez pracownika socjalnego określonych przekonań, wyznawanie pożądanych wartości i przestrzeganie zasad etycznych w praktycznej działalności zawodowej. Podstawowymi wartościami pracy socjalnej są: poufność $\mathrm{w}$ relacjach $\mathrm{z}$ klientem, rozwijanie u podopiecznych samodzielności, wytrwałość w realizacji celów, kierowanie się zasadami sprawiedliwości społecznej, szacunek dla odmienności, wysoki poziom kultury osobistej i zachowań profesjonalnych i inne ${ }^{1}$. Z kolei na trzeci element omawianego kanonu - umiejętności zawodowe - składają się kompetencje z zakresu komunikacji społecznej i interpersonalnej, umiejętności pracy z klientem przy jak najlepszym wykorzystaniu posiadanej wiedzy, opracowywania i wdrażania planów interwencji oraz właściwego korzystania z metod pracy socjalnej (indywidualnej, grupowej, środowiskowej), powadzenia badań społecznych i analizy skuteczności wdrażanych programów społecznych (Wódz, 1999: 139-140).

Źródeł pracy socjalnej w Polsce należy szukać na początku XX wieku, kiedy to dotychczasowe - oddolne i często spontaniczne inicjatywy społeczników (na rzecz poprawy sytuacji bytowej oraz krzewienia oświaty i kultury wśród ludności) - stały się bodźcem do uruchomienia kursów mających na celu podniesienie kompetencji osób działających na rzecz społeczeństwa poprzez przekazanie usystematyzowanej wiedzy z zakresu opieki i pomocy potrzebującym. Kształcenie zawodowe służb społecznych na ziemiach polskich zostało zapoczątkowane jeszcze w okresie zaborów - w sierpniu 1907 r. warszawskie stowarzyszenia katolickie zorganizowały „Kursa społeczne”, w których 716 uczestników poznawało podstawy teoretyczne pracy społecznej. Z kolei pierwsza w Polsce „szkołę pracy społecznej” powstała w 1916 r. przy Wyższych Kursach dla Kobiet im. Baranieckiego w Krakowie, gdzie utworzono Wydział Pracy Społecznej.

1 Zasady etyczne wykonywania profesji pracownika socjalnego zostały zapisane w Kodeksie Etycznym NASW w 1979 roku. W Polsce funkcjonuje Kodeks Etyczny Polskiego Towarzystwa Pracowników Socjalnych. Zob. Siwek, 2009: 97-103. 
Odzyskanie przez Polskę niepodległości w 1918 r. stworzyło możliwości zorganizowania opieki społecznej w ramach struktur państwowych, co przełożyło się na uchwalenie w 1923 r. Ustawy o opiece społecznej2. Dla rozwoju służb społecznych szczególną wagę miało rozporządzenie $O$ opiekunach społecznych i o komisjach opieki społecznej z 1928 r. ${ }^{3}$, które zobowiązywało gminy do ustanowienia w nich opiekunów społecznych. Ich zadaniem był przede wszystkim bezpośredni kontakt z osobami otrzymującymi i mającymi otrzymać świadczenia z opieki społecznej. Opiekun społeczny miał za zadanie współdziałać z gminą w zakresie wykonywania ustawowych obowiązków z zakresu opieki społecznej. Jego obowiązkiem było m.in. nadzorowanie udzielanej przez gminy pomocy oraz kontrolowanie sytuacji finansowej osób, które się zgłaszały po wsparcie. Rozporządzenie nie przewidywało wynagrodzenia dla osób pełniących funkcję opiekuna społecznego - było to stanowisko honorowe i bezpłatne, aczkolwiek osobom je pełniącym przysługiwała ochrona prawna równa urzędnikom państwowym.

Zarówno osoby pełniące funkcję opiekunów społecznych, jak i pozostałe osoby pracujące w sektorze opieki społecznej w znaczącej większości nie posiadały odpowiednich kwalifikacji (por. Stużba społeczna w Polsce, 1928: 30-35). Stąd też konieczne było stworzenie szkół dla wykwalifikowanej kadry zajmującej się opieką i pomocą społeczną. W 1925 r. w Krakowie powstała Szkoła Pracy Społecznej im. Adriana Baranieckiego, kształcąca na poziomie średnim dziewczęta posiadające maturę i ukończone osiemnaście lat. Roczny program kształcenia przygotowywał do pracy w placówkach państwowych, samorządowych i prywatnych instytucjach społecznych (Mikulski, 1976: 10). Były to początki kształcenia pracowników społecznych. Kolejnym krokiem było stworzenie instytucji kształcącej na poziomie wyższym. Pierwszą taką instytucją było założone w 1925 r. przez Helenę Radlińską Studium Pracy Społeczno-Oświatowej Wolnej Wszechnicy Polskiej w Warszawie ${ }^{4}$. Zadania, jakie miała do zrealizowania ta placówka, zostały scharakteryzowane w opracowaniu przygotowanym przez zespół pod kierownictwem Ludwika Krzywickiego:

Cele, które wytknęło sobie Studjum, streszczają w sobie wszystkie dążności nasze w zakresie służby społecznej: należy wydobyć z ukrycia wszystkie siły społeczne, całą tężyznę entuzjazmu i pchnąć je jako inicjatorów nowych dróg działalności kulturalno-oświatowej, nowych sposobów życia, nowych metod zabawy, jako organizatorów różnych zrzeszeń w wogóle wyższego uspołecznienia. (...) ażeby z pożytkiem stanąć na różnych posterunkach służby społecznej, potrzebna jest znajomość najlepszych dróg działania, umiejętność postępowania wśród różnych zbiorowości ludzkich i znajomość wielu jeszcze innych rzeczy. Chodzi o stworzenie licznych zastępów takich wykwalifikowanych pracowników (Stużba społeczna w Polsce, 1928: 11).

\footnotetext{
${ }^{2}$ Ustawa o opiece społecznej z 16 sierpnia 1923, Dz.U. 1923 nr 92 poz. 726.

3 Rozporzadzenie Prezydenta Rzeczypospolitej z dnia 6 marca 1928 r. o opiekunach społecznych i o komisjach opieki społecznej, Dz.U. 1928 nr 29 poz. 267.

${ }^{4}$ Przez pierwsze dwa lata szkoła nosiła nazwę: Studium Pracy Kulturalnej Wolnej Wszechnicy Polskiej.
} 
Nauka na uczelni trwała dwa lata ${ }^{5}$; pierwszy rok był związany z całorocznymi zajęciami w Warszawie, natomiast drugi obejmował konsultacje, seminaria i konferencje oraz zakładał podjęcie pracy zawodowej. Specjalności realizowane w Studium były dostosowane do sytuacji i potrzeb Polski, zaniedbanej kulturalnie i oświatowo w okresie zaborów - kształcono w zakresie: nauczyciela osób dorosłych, organizatora życia kulturalnego młodzieży i dorosłych, bibliotekarza, pracownika opieki nad matką i dzieckiem oraz młodzieżą (Wyrobkowa-Pawłowska, 1991: 16). Zajęcia teoretyczne, prowadzone przez wybitnych profesorów szkół wyższych oraz praktyków ${ }^{6}$, były połączone z praktycznym poznawaniem funkcjonowania placówek społecznych w czasie zajęć zarówno w Polsce, jak i za granicą (w Czechosłowacji, Danii, Francji i in.) (Wyrobkowa-Pawłowska, 1991: 18). Studiować mogły jedynie osoby posiadające przygotowanie merytoryczne (potwierdzone dyplomem wyższej uczelni) i praktyczne w zakresie pracy społecznej lub też osoby bez ukończonych studiów, które posiadały wybitne osiągnięcia w pracy społecznej (Mikulski, 1976: 11). Często instytucje społeczne wysyłały swoich pracowników na studia, opłacając im w czasie ich trwania stypendia (WyrobkowaPawłowska, 1991: 19).

Rozwój szkół rozpoczął trwający przez kolejne dziesięciolecia proces profesjonalizacji zawodu pracownika społecznego (socjalnego), co oznaczało m.in. konieczność zdobywania w drodze kształcenia specjalistycznej wiedzy teoretycznej, doskonalenia umiejętności w drodze doświadczenia zawodowego, posiadania kompetencji pozwalających na cieszenie się uznaniem i autorytetem społecznym oraz dysponowania znaczną autonomią w pracy zawodowej (Wódz, 1999: 137).

Po II wojnie światowej zawód pracownika społecznego, podobnie jak cały polski system opieki społecznej, ulegał dynamicznym przemianom. Jeszcze kilka lat po zakończeniu działań wojennych trwało dość intensywne kształcenie w szkołach dla pracowników społecznych ${ }^{7}$ (również kończenie kursów rozpoczę-

\footnotetext{
${ }^{5}$ Początkowo rok, jednak szybko wydłużono do 2 lat, a od 1937 roku zwiększono do 4 lat.

${ }^{6}$ Wykłady prowadzili profesorowie Wolnej Wszechnicy Polskiej, Szkoły Głównej Gospodarstwa Wiejskiego, Wyższej Szkoły Handlowej, Uniwersytetu Warszawskiego, często uczestnicy tajnych uczelni z okresu zaborów - „uniwersytetu latającego”, czy Towarzystwa Kursów Naukowych. Wśród kadry były takie osoby jak: H. Radlińska, L. Krzywicki, J. Chałasiński: Czarnowski, M. Librachowa, A. Dryjski: Baley, M. Odrzywolski, A.B. Dobrowolski, K. Krzeczkowski: Rychliński, M. Jaroszyński, J. Strzelecki, M. Orzęcki, J. Muszkowski, M. Godecki, K. Korniłowicz, Z. Kobyliński, F. Czerwijowski, Cz. Wroczyński, I. Jurgieliczowa, A. Miller (Csorba), J. Millerowa, A. Walicka-Chmielewska, J. Korczak, M. Kasprzak, A. Zelwerowicza, a nawet odwiedzający Polskę J. P. Piaget. Zob. Wyrobkowa-Pawłowska, 1991: 19-20.

7 W czerwcu 1945 r. Ministerstwo Pracy i Opieki Społecznej utworzyło Centrum Szkolenia Pracowników Opieki Społecznej w Łodzi, w którym wykładowcami centrum byli praktycy pracy opiekuńczej oraz wykładowcy akademiccy (m.in. H. Radlińska). Na początku $1946 \mathrm{r}$. w Krakowie Towarzystwo Uniwersytetów Robotniczych zorganizowało Wyższą Szkołę Nauk
} 
tych w czasie wojny), jednakże ideologia obowiązująca w czasach stalinowskich spowodowała likwidację systemu opieki społecznej (w tym badań naukowych z zakresu nauk społecznych, struktur państwowych opieki i pomocy społecznej, opieki i pomocy realizowanej przez podmioty niepubliczne, większości szkół dla służb społecznych).

Po „odwilży październikowej” rozpoczął się proces tworzenia sieci powiatowych opiekunów społecznych ${ }^{8}$, których zadaniem było organizowanie i koordynowanie opieki społecznej przy współpracy z organami władzy i administracji państwowej oraz innych instytucji działających na poziomie powiatu (zob. Zieliński, 1960: 33-34). Wymagania w zakresie kompetencji opiekunów społecznych były (jak na ówczesne realia) teoretycznie bardzo wysokie - powinni posiadać wyższe wykształcenie oraz dwuletnią praktykę zawodową lub mieć wykształcenie średnie i pięcioletnią praktykę. Jednakże możliwość zatrudniania osób nieposiadających takich kwalifikacji była nagminnie wykorzystywana - można bowiem było w przypadku braku wymaganych kwalifikacji zatrudniać na podstawie „właściwej postawy społecznej" oraz wykazania zdolności i uzdolnień w dotychczasowej pracy.

Powiatowi opiekunowie społeczni mieli za zadanie organizować i koordynować sieć terenowych opiekunów społecznych, których zadaniem było działanie w swoim miejscu zamieszkania (na osiedlu, wsi). Kandydaci na terenowych opiekunów społecznych byli wskazywani przez lokalne organizacje społeczne lub rady narodowe i powoływani za swoją zgodą na czas nieokreślony. Swoje obowiązki wykonywali honorowo (nieodpłatnie).

Urządzony w ten sposób system pomocy społecznej okazał się niewydolny. Zamiast oczekiwanych skoordynowanych działań opiekunów społecznych na rzecz potrzebujących, działali słabo opłacani powiatowi terenowi opiekunowi społeczni oraz pracujący ochotniczo terenowi opiekunowie społeczni. Prestiż opiekuna społecznego był bardzo niski - nie był on urzędnikiem docenianym, często natomiast wykonywał prace biurowe niezwiązane z zajmowanym stanowiskiem (Informacja o przebiegu szkolenia..., 1962: 57-58; Rymuszko, 1968: 1).

Powszechnym problemem był niedobór ilościowy zarówno powiatowych, jak i terenowych opiekunów społecznych. Szczególnie trudna była sytuacja na wsiach,

Społecznych. W połowie maja 1948 r. otwarto w Warszawie Ośrodek Szkoleniowy Pracowników Opieki Społecznej.

${ }^{8}$ Opiekunowie społeczni mieli swoje siedziby przy powiatowych radach narodowych lub ich odpowiednikach - w miastach stanowiących powiaty miejskie działali miejscy opiekunowie społeczni, a w miastach wyłączonych z województw dzielnicowi opiekunowie społeczni. Zob. Uchwała Nr 92 Rady Ministrów z dnia 5 marca 1959 r. w sprawie powołania opiekunów społecznych, M.P. 1959, nr 32 poz. 145.

9 Zarządzenie Ministra Pracy i Opieki Społecznej z dnia 27 października 1959 r. o zakresie i trybie działania opiekunów społecznych, M.P. 1959 nr 93 poz. 496. 
gdzie bardzo często nie było opiekunów społecznych albo nie podejmowali oni żadnej aktywności. Specyfika funkcji terenowego opiekuna społecznego, zwłaszcza brak wynagrodzenia za pracę, skutkowały poważnym niedoborem kadr, który nierzadko uzupełniano jedynie na poziomie zestawień administracyjnych poprzez dopisywanie przypadkowych nazwisk (Rak, 1963: 5).

Równie niekorzystnie wyglądał inny wyznacznik profesjonalnej pracy socjalnej - wykształcenie. Szkolenia dla opiekunów społecznych, jeżeli w ogóle były organizowane na danym terenie, często nie były systematyczne, a także przeprowadzane w mało atrakcyjny sposób, co przekładało się na małą frekwencję (Rak, 1970: 6; Rak, 1972: 247; Pismo okólne Nr 10/2...) opiekunów społecznych, Dz.Urz. MPiOS nr 2 poz. 1. Nierzadko zamiast regularnych kursów odbywało się jedynie doraźne instruowanie opiekunów społecznych (Bogacz, 1962: 19-20).

Ważnym krokiem w kierunku profesjonalizacji było uzawodowienie dotychczasowych działań podejmowanych przez opiekunów społecznych. Zarządzenie Ministra Oświaty z dnia 4 listopada 1966 r. wprowadziło nazwę nowego zawodu - „pracownik socjalny” ${ }^{10}$. Mimo iż zmiana wydawała się niewielka (dotychczasowi etatowi opiekunowie społeczni zostali pracownikami socjalnymi), to wielu wierzyło w rozpoczęcie nowego okresu w budowaniu profesjonalnych służb społecznych. Aleksander Kamiński pisał:

praca socjalna jest czymś zasadniczo różnym od opieki społecznej i służby społecznej. Wyzwolona ostatecznie z ograniczeń dobroczynności, oparta na budżecie państwa i wielkich struktur społecznych państwa socjalistycznego (...) praca socjalna ma zapewniony trwały fundament materialny, umożliwiający rozwinięcie szerokiego frontu aktywności społeczno-wychowawczej (...). (Kamiński, 1974: 75)

Ustanowienie zawodu 'pracownik socjalny' było niewątpliwie krokiem w stronę profesjonalizacji dotychczasowych działań z zakresu opieki i pomocy społecznej. Wsparcie finansowe i organizacyjne państwa miało pomóc w zastąpieniu istniejących, niewydolnych służb społecznych, wykwalifikowanymi pracownikami socjalnymi.

Wprowadzenie w 1966 r. nazwy oddzielnego zawodu "pracownik socjalny”, połączono z otwarciem w tym samym roku Państwowych Szkół Pracowników Socjalnych w Warszawie (Hibel, 1976: 9-15) i Poznaniu (zob. Bloch, 1976: 29-33; Król, Bloch, 2007: 98), kształcących na poziomie średnim. W 1967 r. otwarto podobne szkoły w Łodzi i Krakowie, rok później we Wrocławiu, a w latach siedemdziesiątych powstawały placówki w kolejnych miastach (Oleszczyńska, 1976: 1).

${ }^{10}$ Zarządzenie Ministra Oświaty z dnia 4 listopada 1966 r. (Nr SZ2-0101-48/66) w sprawie zmiany nomenklatury zawodów i specjalności, do których przygotowują szkoły zawodowe, Dz. Urz. Min. Oświaty 1966, nr 16 poz. 193. 
Kształcenie w Państwowych Szkołach Pracowników Socjalnych trwało dwa lata, początkowo jedynie $\mathrm{w}$ trybie dziennym ${ }^{11}$. Przyjmowano osoby poniżej 40 . roku życia, posiadające świadectwo dojrzałości uprawniające do podjęcia studiów wyższych. Program realizowany przez szkoły był bardzo zróżnicowany, dzięki czemu uwzględniał szeroki zakres obowiązków osób pracujących w zawodzie pracownika socjalnego, mających możliwość zatrudnienia w różnych zakładach pracy, instytucjach i organach administracji państwowej (Rak, 1972: 248).

Zakres kompetencji pracowników socjalnych wykształconych w nowo powołanych placówkach obejmował następujące kwestie:

poprawa warunków materialnych i socjalnych oraz stwarzanie pomyślnych warunków wychowawczych jednostce i rodzinie; pomoc dla młodzieży i dzieci pozbawionych właściwej opieki; rehabilitacja społeczna i zawodowa; zapewnienie opieki ludziom starym; walka ze zjawiskami społecznego marginesu: alkoholizmem, prostytucją itd.; pomoc dla pracowników w zakładach pracy. (Założenia programowo-organizacyjne..., 1973: 5)

Wykształcenie wyższe pracownicy społeczni mogli uzyskać od 1956 r. na Uniwersytecie Warszawskim oraz na Uniwersytecie Łódzkim od 1957 r. (Mikulski, 1972: 8-9).

Na początku lat sześćdziesiątych możliwość uzyskania tytułu magistra ze specjalnością z polityki społecznej otwarła warszawska Szkoła Główna Planowania i Statystyki (dzisiejsza Szkoła Główna Handlowa).

W podnoszeniu kwalifikacji opiekunów społecznych oprócz kursów i szkół miały być pomocne wydawane przez Departament Pomocy Społecznej Ministerstwa Zdrowia i Opieki Społecznej publikacje (m.in. Poradnik Opiekuna Społecznego, Wskazówki metodyczne dla opiekunów społecznych, kwartalnik „Biuletyn Opiekuna Społecznego"12).

Funkcjonowanie nowego zawodu - pracownika socjalnego - nie przyniosło oczekiwanych rezultatów. Wykształceni na poziomie średnim, a nawet wyższym, pracownicy socjalni wykonywali pracę jedynie administracyjną, a bezpośredni kontakt $\mathrm{z}$ klientem opieki społecznej mieli terenowi opiekunowie społeczni. Efektywność pracy opiekunów terenowych nie zwiększała się, mimo że ich liczba przekraczała w skali całego kraju sześćdziesiąt tysięcy, oraz mimo prowadzenia

11 Pierwszy wydział zaoczny powstał przy szkole warszawskiej w 1969 r., o czym będzie mowa w kolejnym rozdziale pracy.

12 Biuletyn wydawało Kolegium Redakcyjne przy Departamencie Pomocy Społecznej Ministra Zdrowia i Opieki Społecznej w Warszawie. Od 1971 r. czasopismo nosiło nazwę „Opiekun Społeczny”. Adresowano było przede wszystkim do opiekunów społecznych, którym miało służyć w usprawnianiu pracy zawodowej. Podejmowało tematy związane z pracą opiekunów społecznych na wszystkich szczeblach, zamieszczało relacje pisane przez terenowych opiekunów społecznych, którzy dzielili się swoimi doświadczeniami. Ponadto ma jego łamach podawano zmiany prawne w przepisach dotyczących pomocy społecznej oraz plany działalności ministerstwa na kolejne lata. 
dla nich szkoleń zawodowych. Podstawowe przyczyny tego zjawiska wydają się dwojakie. Po pierwsze, byli to pracownicy honorowi, wykonujący swoje obowiązki dobrowolnie, a to nie wystarczało do wywiązywania się z trudnych zadań, wymagających często natychmiastowego działania. Druga przyczyna leżała w wieku pracowników społecznych - były to w większości osoby starsze, $\mathrm{z}$ wykształceniem podstawowym, nie potrafiące (mimo dobrych chęci) odpowiednio klasyfikować potrzeb i skutecznie interweniować. Pozyskiwanie młodych osób na te stanowiska nie przynosiło większych rezultatów (Kaźmierczak, 1989: 38-39).

Istotna zmiana koncepcji opieki i pomocy społecznej, która nastąpiła pod koniec lat sześćdziesiątych i trwała do początku lat dziewięćdziesiątych, polegała na integracji systemu opieki społecznej z ochroną zdrowia. Efektem jej realizacji było powołanie (przeniesienie) ośrodków opiekuna społecznego przy przychodniach obwodowych, oraz stopniowe zastępowanie dotychczasowych (honorowych) opiekunów społecznych przez pracowników socjalnych pracujących na etacie, wykształconych w profilowanych pod ich kątem szkołach (Kaźmierczak, 1989: 39).

Proces ten rozpoczął się w 1969 r., gdy 8 marca weszła w życie Instrukcja nr 1/69 Ministra Zdrowia i Opieki Społecznej z dnia 31 stycznia 1969 r. w sprawie ośrodka opiekuna społecznego ${ }^{13}$. Powołane wtedy ośrodki miały z założenia stanowić uzupełnienie dla działających od kilku lat opiekunów społecznych i działać przy wszystkich przychodniach obwodowych ([Zet], 1967: 5; Oleszczyńska, 1978: 29). Z kolei związanie się opieki i pomocy społecznej ze służbą zdrowia na poziomie wojewódzkim dokonało się w latach 1972-1975, kiedy to utworzono wojewódzkie ośrodki opiekuna społecznego w ramach struktur organizacyjnych Wojewódzkich Szpitali Zespolonych (Łopato, 1989: 11). Celem ich powołania było nadzorowanie i wspieranie opiekunów społecznych i pracowników socjalnych w zakresie organizacji pracy i podnoszenia kwalifikacji, a także analizowanie stanu i prognozowanie rozwoju opieki i pomocy społecznej na terenie województwa (Kaźmierczak, 1985: 39-40; Kaźmierczak, 1989: 38).

Celem powstania ośrodków była chęć usprawnienia współpracy pomiędzy służbą zdrowia a opieką społeczną i w efekcie poprawa poziomu świadczeń opiekuńczo-zdrowotnych w środowisku lokalnym. W nowo powstałej instytucji upatrywano również szansę na poprawę jakości szkoleń dla opiekunów społecznych, które dotąd najczęściej nie wychodziły poza niezbędne minimum, czyli omówienia zmian w przepisach prawnych i bieżących żądań.

13 Instrukcja nr 1/69 Ministra Zdrowia i Opieki Społecznej z dnia 31 stycznia 1969 r. (CS 671-3/69) w sprawie ośrodka opiekuna społecznego, Dz. Urz. MZiOS z dn. 8 marca 1969 r. nr 4 poz. 12. Instrukcja ta określała zadania zawarte w art. 20 ust. 1 pkt 5 Rozporządzenia Ministra Zdrowia i Opieki Społecznej z dnia 31 lipca 1967 r. w sprawie organizacji otwartej opieki zdrowotnej, Dz.U. $1967 \mathrm{nr} 36$ poz. 183. 
Proces przekształceń opieki społecznej w latach siedemdziesiątych i osiemdziesiątych przyniósł dość znaczącą zmianę - praca opiekuna społecznego (pracownika socjalnego) uległa etatyzacji. Co prawda funkcjonowała jeszcze sieć opiekunów społecznych, działających na zasadach wolontariatu, jednakże ich zadania ograniczono do przygotowania i wstępnej diagnozy potrzeb opiekuńczych. Natomiast ostateczna diagnoza, plan pomocy i działanie pomocowe należały już do etatowego, rejonowego pracownika (asystenta) socjalnego, zatrudnionego w Ośrodku Opiekuna Społecznego (Wódz, 1982: 33-35).

Równolegle do działań przekształcających system pomocy i opieki społecznej starano się zapewnić kadrę wyszkoloną w tym kierunku. 28 stycznia 1974 r. Prezydium Rządu zatwierdziło przygotowany przez Kolegium Ministerstwa Zdrowia i Opieki Społecznej program rozwoju zawodowej służby socjalnej w latach 1975-1990. Zakładano w nim stworzenie do 1990 r. sieci zawodowych pracowników socjalnych, działających w każdej gminie, a w miastach w rejonach zamieszkałych przez 3 tys. ludności. Pracownicy socjalni mieli być fachowcami, posiadać odpowiednią wiedzę teoretyczną i umiejętności praktyczne, by sprawnie radzić sobie z problemami lokalnymi (Oleszczyńska, 1976: 25). Docelowo planowano zatrudnić 7,5-8 tys. pracowników socjalnych ${ }^{14}$. Pracownicy socjalni mieli wykonywać swoją pracę $\mathrm{w}$ ścisłej współpracy ze służbą zdrowia. Ponadto program ten zakładał podniesienie jakości pracy terenowych opiekunów społecznych (Oleszczyńska, 1978: 2).

$\mathrm{Z}$ uwagi na rozwój służb społecznych i tym samym zwiększające się zapotrzebowanie na wykwalifikowanych pracowników dalszemu rozwojowi uległa sieć szkół, które umożliwiały zdobycie wykształcenia średniego z zakresu opieki społecznej (J. Mikulski, 1972: 9). Zdecydowanie najwięcej osób kształciło się w państwowych szkołach dla pracowników socjalnych, których sieć systematycznie rozwijano (M. K. [M. Karczewski], 1975: 29). Studia wyższe z zakresu pracy w służbach społecznych można początkowo było odbyć na trzech uczelniach. Taką możliwość oferowały Instytuty Nauk Społecznych Uniwersytetów Warszawskiego i Łódzkiego oraz SGPiS (Mikulski, 1972: 9). Zarówno szkoły, jak i uczelnie zaczęły oferować zdobywanie wykształcenia również w trybie zaocznym (Leś, 1990: 98; Oleszczyńska, 1974: 54).

Jeżeli chodzi o zatrudnienie absolwentów średnich szkół dla pracowników socjalnych to kolejne roczniki absolwentów w coraz mniejszym stopniu znajdowały etat w instytucjach resortu zdrowia i opieki społecznej, mimo że wciąż wykonywanie tej profesji nie łączyło się ani z prestiżem ani z zadowalającą płacąa ${ }^{15}$.

14 Dane z czerwca 1974 roku mówią o 812 zatrudnionych pracownikach socjalnych, w kolejnych latach (również dane z końca czerwca) wzrost ich liczby wyglądał następująco: 1975 r. - 1183 pracowników socjalnych, 1976 r. - 1443, 1977 r. - 1698. Oleszczyńska, 1978: 2).

15 Dane z Państwowej Szkoły Pracowników Socjalnych w Warszawie z lat 1968-1971 mówią o 30-48\% zatrudnieniu absolwentów w zawodzie pracownika socjalnego w zależności od rocznika, oraz o tendencji spadkowej w tym zakresie. Hiblowa, 1972: 33-34. 
Przemiany społeczne i gospodarcze zapoczątkowane w Polsce w 1989 roku objęły również system opieki i pomocy społecznej, którego reformę rozpoczęto od zmiany podstawy prawnej, czyli ustawy o opiece społecznej z 1923 roku. Uchwalona w 1990 roku Ustawa o pomocy społecznej jako jeden z priorytetów stawiała sobie rozwój pracy socjalnej rozumianej jako „działalność zawodową, skierowaną na pomoc osobom i rodzinom we wzmocnieniu lub odzyskaniu zdolności do funkcjonowania w społeczeństwie oraz na tworzeniu warunków sprzyjających temu celowi” ${ }^{\prime \prime}$. W połowie lat dziewięćdziesiątych zaczęto reformować system kształcenia pracowników socjalnych w kierunku profesjonalizacji tego zawodu. Szkoły kształcące przyszłych pracowników socjalnych otrzymały wytyczne - ramowy plan nauczania, minima programowe, oraz zakres umiejętności wymaganych się od profesjonalnie przygotowanego pracownika socjalnego (m.in. umiejętności metodologiczne, społeczne, menedżerskie, stosowania wiedzy z zakresu prawa, podejmowania decyzji i szybkiej interwencji socjalnej, korzystania z literatury obcojęzycznej) ${ }^{17}$. Stworzono także dwa stopnie specjalizacji zawodowej dla czynnych zawodowo pracowników socjalnych, których uzyskanie wymaga określonego stażu pracy oraz zdania egzaminu dyplomowego ${ }^{18}$.

Kolejną decyzją, której skutkiem miało być jeszcze skuteczniejsze dostosowanie kwalifikacji pracowników socjalnych do zapotrzebowania systemu pomocy społecznej, było wprowadzanie w ramach zawodu pracownika socjalnego specjalności. Obecnie pracownik socjalny może się specjalizować w następujących kierunkach: praca socjalna $\mathrm{z}$ rodziną z problemami opiekuńczo-wychowawczymi, praca socjalna $\mathrm{z}$ osobą i rodziną z problemem przemocy, praca socjalna $\mathrm{z}$ osobami niepełnosprawnymi i ich rodzinami, praca socjalna $\mathrm{z}$ osobami z zaburzeniami psychicznymi i ich rodzinami, praca socjalna z osobami starszy$\mathrm{mi}$, praca socjalna $\mathrm{z}$ osobami bezrobotnymi, praca socjalna $\mathrm{z}$ osobami uzależnionymi, praca socjalna $z$ osobami bezdomnymi, praca socjalna $\mathrm{z}$ cudzoziemcami, mniejszościami narodowymi i etnicznymi, praca socjalna ze społecznością lokalną oraz każdej innej specjalności jeżeli tego wymagają potrzeby regionu czy środowiska lokalnego ${ }^{19}$.

Mimo stopniowego podnoszenia kwalifikacji pracowników socjalnych sama praca socjalna pozostawała w tle innych świadczeń otrzymywanych przez klien-

16 Ustawa z dnia 29 listopada 1990 r. o pomocy społecznej, Dz.U. 1990 nr 87 poz. 506.

17 Decyzja Nr 7 Ministra Pracy i Polityki Socjalnej z dnia 4 października 1995 r. w sprawie ustalenia dokumentacji programowej dla zawodu pracownik socjalny, Dz. Urz. Min. Pr. 1995 Nr 6 poz. 7; Sikora, 2002: 38-39.

18 Rozporzadzenie Ministra Pracy i Polityki Socjalnej z dnia 5 marca 1997 r. w sprawie stopni specjalizacji w zawodzie „pracownik socjalny”, Dz.U. 1997 nr 24 poz. 125.

19 Rozporzadzenie Ministra Pracy i Polityki Społecznej z dnia 17 kwietnia 2012 r. w sprawie specjalizacji w zawodzie pracownik socjalny, Dz.U. 2012 nr 0 poz. 486. 
tów pomocy społecznej. Dane z lat 1994-2004 mówią, że liczba świadczeniobiorców, którzy korzystali z pomocy wyłącznie w formie pracy socjalnej oscyluje wokół $18 \%$, co więcej, liczba ta w ciągu dekady nie wzrastała. Natomiast zdecydowana większość świadczeniobiorców otrzymywała pomoc materialną, zaspakajającą bieżące potrzeby konsumpcyjne (Zalewski, 2005: 162-163).

Uchwalona w 2004 roku ustawa o pomocy społecznej ${ }^{20}$ nie przyniosła rewolucji w działalności pracowników socjalnych. Zakładano, że elementem zwrotnym w dotychczasowej praktyce świadczenia usług z zakresu pomocy społecznej będzie kontrakt socjalny, niemniej jednak brak odpowiedniego przygotowania kadr nie pozwala na prawidłowe i powszechne stosowanie tego narzędzia (Rymsza, 2012: 205).

Funkcjonujący od lat źle skonstruowany system pomocy społecznej, który jedynie utrwala grono osób wymagających wsparcia zamiast skutecznie motywować ich do wyjścia z trudnej sytuacji życiowej, powoduje w pracownikach socjalnych, niewidzących efektów swojej pracy, frustrację i wypalenie zawodowe (Andrzejewski, 2009: 95). Efekty pracy socjalnej zapisywane w kolejnych aktach prawnych mają charakter jedynie „listy życzeń” (Beckett, 2012: 197-198), gdyż praktyka funkcjonowania instytucji pomocowych uniemożliwia ich skuteczną realizację. Praca socjalna istnieje dużo bardziej w zestawieniach i statystykach niż w codziennej praktyce, innymi słowy ma charakter pozorowany (zob. Trawkowska, 2007). Najczęściej stosowany obecnie model pracy socjalnej to model dystrybucyjny, polegający na pomocy doraźnej ( $\mathrm{w}$ formie świadczeń i usług) dla osób, które dostarczą do ośrodka pomocy społecznej dokumentacją potwierdzającą możliwości przyznania świadczeń (Krasiejko, 2010: 50, 57).

Proces profesjonalizacji zawodu pracownika socjalnego, który formalnie jest już na poziomie dość zaawansowanym, w praktyce ma jeszcze wiele elementów wymagających rozwoju. Polski pracownik socjalny to wciąż osoba o niskim statusie zawodowym, społecznym i ekonomicznym (Bieńko, 2012: 165), która z powodu specyficznej organizacji systemu pomocy społecznej najczęściej nie ma możliwości skorzystania z podstawowych narzędzi przypisanych do swojej profesji. Pozostaje mieść nadzieję, że siła ponad stuletnich doświadczeń polskich służb społecznych pomoże w ciągu najbliższych lat przezwyciężyć biurokratyczne ograniczenia na rzecz aktywnej pracy socjalnej której efektem będzie z jednej strony usamodzielnienie klientów pomocy społecznej, a z drugiej osiągniecie przez pracę socjalną statusu profesji.

${ }^{20}$ Ustawa z dnia 12 marca 2004 r. o pomocy społecznej, Dz.U. 2004 nr 64 poz. 593. 


\section{Literatura}

Andrzejewski M. (2009). Prawo jako narzędzie wspierania rodziny w środowisku lokalnym (rozważania sceptyczne). „Studia Edukacyjne” 10

Beckett Ch. (2012). Podstawy teorii dla praktyków pracy socjalnej. Warszawa

Bieńko M. (2012). Pomiędzy jałmużnikiem a profesjonalistą. Wybrane płaszczyzny realizacji roli pracownika socjalnego $w$ perspektywie badawczej. [W:] W stronę aktywnych służb społecznych. Red. T. Kaźmierczak, M. Rymsza. Warszawa

Bloch T. (1976). Społeczno-wychowawcze funkcje szkoły pracowników socjalnych. Refleksje pedagogiczne w oparciu o doświadczenia szkoły poznańskiej, „Opiekun Społeczny” 1

Bogacz M. (1962). Podnoszenie kwalifikacji opiekunów społecznych. „Biuletyn Opiekuna Społecznego" 5

Hibel C. (1976). Dziesiąty rok kształcenia pracowników socjalnych w szkole warszawskiej, „Opiekun Społeczny" 1

Informacja o przebiegu szkolenia opiekunów społecznych w województwie krakowskim. (1962). „Biuletyn Opiekuna Społecznego" 2

Kamiński A. (1974). Funkcje pedagogiki społecznej. Praca socjalna i kulturalna, wyd. 2 popr. i uzup. Warszawa

Kaźmierczak T. (1985). O wojewódzkich ośrodkach opiekuna społecznego. „Praca Socjalna” 1

Kaźmierczak T. (1989). O wojewódzkich ośrodkach opiekuna społecznego - raz jeszcze. „Praca Socjalna" 1

Krasiejko I. (2010). Metodyczne działanie pracowników socjalnych. [W:] Praca socjalna i wolontariat w pomocy społecznej. Red. M. Mirowska. Częstochowa

Kryczyńska I. (1969). Wskazówki metodyczne dla opiekunów społecznych. Warszawa

Leś E. (1990). Dziesięciolecie kształcenia uniwersyteckiego pracowników socjalnych, „Praca Socjalna" 1-2

Leśniak-Berek E., Wódz K. (2009). Dylematy kształcenia dla pracy socjalnej. Z doświadczeń Studium Pracy Socjalnej Uniwersytetu Śląskiego. [W:] Współczesne wyzwania i metody pracy socjalnej. Red. W. Szymczak. Lublin

Łopato J. (1989). Zarys rozwoju pomocy społecznej w Polsce Ludowej. „Polityka Społeczna” 10

M. K. [M. Karczewski]. (1975). O pomocy społecznej w sejmie. „Opiekun Społeczny” 3

Marynowicz-Hetka E. (1977). Warsztat pracownika socjalnego. Warszawa

Mikulski J. (1972). Rola i zadania państwowych szkół pracowników socjalnych z procesie realizacji nowej polityki socjalnej. „Opiekun Społeczny” 3

Mikulski J. (1976). Przygotowanie zawodowe pracownika socjalnego. Warszawa

Oleszczyńska A. (1974). [brak tytułu], „Opiekun Społeczny” 2

Oleszczyńska A. (1976). Pracownik socjalny. Rozważania z okazji jubileuszu, „Opiekun Społeczny" 1

Oleszczyńska A. (1978). Pracownik socjalny w pomocy społecznej. Warszawa

Pismo okólne Nr 10/2 Ministerstwa Pracy i Opieki Społecznej - Departament Pomocy Społecznej - z dnia 16 lutego 1960 r. Znak: Ss. 642-7/60 w sprawie zasad szkolenia powiatowych (miejskich, dzielnicowych) opiekunów społecznych, Dz. Urz. MPiOS nr 2 poz. 1.

Poradnik opiekuna społecznego. (1960). Warszawa;

Poradnik opiekuna społecznego. (1964) wyd. 2. Red. J. Rutkiewicz, E. Strzelecki, Z. Lancmański. Warszawa (i dodruk z roku 1965).

Poradnik pracownika socjalnego. (1973). Red. J. Rosner. Warszawa 
Rak S. (1963). Uwagi na temat organizacji pracy opiekunów społecznych. „Biuletyn Opiekuna Społecznego" 4

Rak S. (1970). Kilka uwag o działalności opiekunów społecznych w 1969 r. „Biuletyn Opiekuna Społecznego" 1

Rak S. (1972). Opiekunowie społeczni. [W:] Polityka społeczna i służby społeczne w PRL. Red. J. Rosner. Warszawa

Rymsza M. (2012). W stronę pracy środowiskowej i nowych ról zawodowych pracowników socjalnych. [w:] Pracownicy socjalni i praca socjalna w Polsce. Między służba społeczna a urzędem. Red. M. Rymsza. Warszawa

Rymuszko A. (1968). Instytucja opiekunów społecznych w m. st. Warszawie. „Biuletyn Opiekuna Społecznego" 4

Sikora P. (2002). Profesjonalizacja pracy socjalnej w warunkach transformacji systemu pomocy społecznej w województwie opolskim. [W:] Pracownik socjalny. wybrane problemy zawodu $z$ okresie transformacji społecznej. Red. J. Brągiel, A. Kurcz. Opole

Siwek A. (2009). O potrzebie istnienia kodeksu etyki zawodowej pracowników socjalnych. „Praca Socjalna" 5

Stużba społeczna w Polsce. (1928). Red. L. Krzywicki. Warszawa

Trawkowska D. (2007). Działania pozorne w pomocy społecznej. Przypadek (i przypadłość) pracy socjalnej. „Problemy Polityki społecznej” 10

Wódz K. (1982). Stużby społeczne w Polsce. Geneza, kierunki rozwoju, metody pracy. Katowice

Wódz K. (1999). Profesjonalizm jako podstawowy wyznacznik tożsamości zawodowej pracownika socjalnego. Katowice

Wyrobkowa-Pawłowska W. (1991). Studium Pracy Społeczno-Oświatowej Wolnej Wszechnicy Polskiej. [W:] Kształcenie pracowników socjalnych. Red. E. Leś, J. Rosner. Warszawa

Zalewski D. (2005). Opieka i pomoc społeczna. Dynamika instytucji. Warszawa

Założenia programowo-organizacyjne Medycznego Studium Zawodowego. Wydział Pracowników Socjalnych, MZiOS, Warszawa 1973,

Zieliński F. (1960). Organizacja sieci terenowych Opiekunów Społecznych. „Biuletyn Opiekuna Społecznego" 1

\section{From a Social Activist to a Professional - the Evolution of the Occupation of a Social Worker in Poland}

\section{Summary}

The source of the social work in Poland may be found at the beginning of XX century, when the previous - the rank-and-file and frequently spontaneous initiatives of social activists (in order to improve the living conditions as well as to promote education and culture among the population) became a stimulus to start courses aiming at improving the competence of those acting for the society by passing the systematized knowledge from the field of care and help to the ones in need.

Gaining independence by Poland in 1918 made it possible to organise social care within the state structures, which in consequence led to the Bill of Social Care in 1923. Both those having the function of social guardians and other people working in the sector of social care did not have appropriate qualifications. It was therefore necessary to establish schools for qualified 
staff dealing with social care and help. In 1925 in Cracow the Adrian Baraniecki School of Social Work was established. It educated girls of age with Matura exam at the secondary level. The Free Polish University of Social and Educational Work established by Helena Radlińska in 1925 in Warsaw was the first institution educating at the higher level.

Lasting for the next decades the development of schools started the process of making the occupation of social worker professional, which meant the necessity of: gaining theoretical knowledge on the way of professional education, improving the skills by professional experience, having competences which gave the appreciation and social authority, having great autonomy in professional work among others.

After the Second World War the occupation of a social worker as well as the whole Polish social care system underwent dynamic changes. A few years after the war activities finished there was rather intense education at schools for social workers, however, the ideology in the times of Stalinism caused the liquidation of the social care system (including science research in the field of social studies, state structures concerning social care and help, help and care realized by non-public institutions, the majority of schools for the social workers).

In the second half of the 1950s. the process of forming the networks of the district social guardians started. The task of the aforementioned was to organize and coordinate social care in cooperation with the authorities and state administration and other institutions working at the level of a district.

Organised in this was system of the social help turned out to be inefficient. Instead of expected coordinated actions of social guardians, poorly paid district local social guardians and voluntary local social guardians worked for the needing ones. The prestige of a social guardian was very low - they were not appreciated civil servants, and they frequently did office work not related to the their position. The lack of both district and local social guardians was a common problem. A specially difficult situation was in the villages where there were very often no social guardians or they did not engage in any type of activity.

The introduction of the name „social worker” for the separate profession in 1966 was connected with the establishment of the State Schools of Social Workers in Warsaw and Poznań, which educated at the secondary level and which number was systematically growing.

The crucial change of the concept of social care and help, which took place at the end of 1960s. and lasted until the beginning of the 1990s, was based on the integration of the social care system with the health care. The effect of the aforementioned was the appointment (transfer) of the centres of social guardians to the district clinics and gradual replacement of the hitherto (honour) social guardians by the social workers who worked full time and were educated in the appropriate schools.

Social and economic changes which started in Poland in 1989 included also the system of social care and help, which reform began with the change of legal basis, meaning the bill of social care from 1923. Enacted in 1990 The Bill of Social Help set as one of the priorities the development of social work understood as, „professional activity aimed at helping persons and families in strengthening or regaining the ability to function in the society and in creating the conditions which would help this goal". From the second half of the 1990s. the system of educating social workers was being reformed in the direction of making the occupation professional. The schools educating the future social workers gained the guidelines - frame plan of teaching, programme minimum and the range of skills required for a professionally prepared social worker (methodological, social, manager skills as well as the ability to use the knowledge in the field of law, making decisions and quick social interventions, using the foreign literature etc.). 
Although the social workers were gradually raising their qualifications, the social work itself was still in the background of other benefits received by the clients of social help. The data from 1994-2004 states that the number of beneficiaries who used only social work is about 18\% and, what is more, the number did not grow over the decade. The majority of the beneficiaries received the material help which satisfied their current consumer needs.

The bill of social work enacted in 2004 did not bring any revolution in the activities of social workers. It was assumed that the turning element of the current practice of providing service in the field of social help will be the social contract, however, the lack of appropriate preparation of the staff does not allow the correct and common usage of this tool.

The ill-structured system of social help, which has been functioning for years, only preserves the group of people who need help instead of effectively motivating them to find the solution for their difficult life situation. The whole system causes the social workers, who do not see the effects of their work, feel frustrated and professionally burnout. The effects of social work written in subsequent legal acts have a character of „wish lists” as the practice of functioning of help institutions makes it impossible to work effectively. Social work exists rather in tables and statistics than in everyday practice, and therefore it has a pretend character. The most frequently used model of social work nowadays is the distributional model consisting in relief help (in the form of benefits and services) for those who provide the centres of social help with the documentation confirming the possibility of granting the benefits.

The process of making the occupation of social worker professional, which formally is at the rather advanced level, in practice has numerous elements requiring development. Polish social worker is still a person of low professional, social and economic status who does not have the opportunity to use the basic tools connected with their profession because of the specific organization of the system of social help. One may hope that the power of over hundred year experience of Polish social workers will help in coming years to overcome the bureaucratic limits for active social work, which effect will be on one hand the clients of social help becoming independent, and on the other hand the social work gaining the status of a profession. 